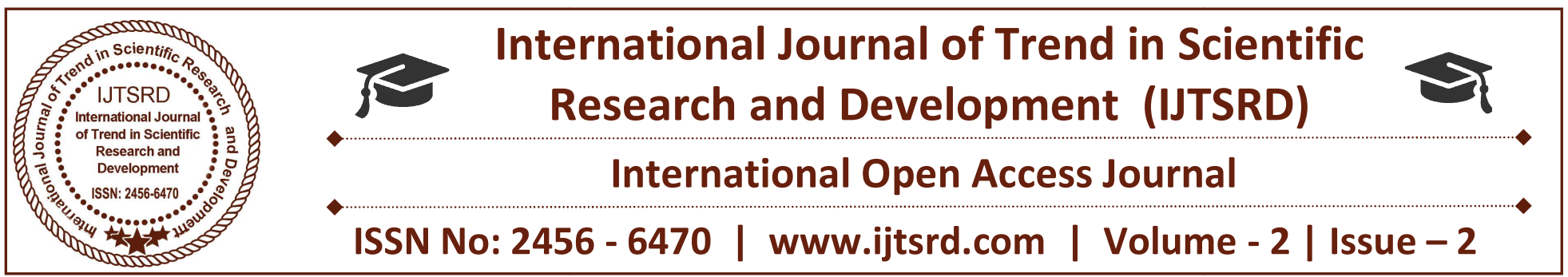

\title{
A Review on Phytochemical and Pharmacological studies of Berberis Aristata
}

\author{
Dr. Siva Rami Reddy E \\ Research Scholar, Faculty of Homoeopathy, \\ Tantia University, Sri Ganganagar, Rajasthan, India
}

\begin{abstract}
Phytochemical studies shows that plant Berberis aristata contains mainly yellow colored alkaloids Berberine, oxyberberine, berbamine, aromoline, a protoberberine alkaloid karachine, palmatine, oxycanthine and taxilamine and tannins, sugar, starch. The plant has effective pharmacological action and shows promising future for further researches. This review aims to highlight the ethnobotany, pharmacognostic and pharmacological uses of Berberis aristata. It is a red listed endemic medicinal plant species of conservation concern and has become very important in recent years due to its rarity and huge demand in the medicinal plant sector. However, many other species such as Berberis asiatica Roxb., Berberis lycium Royle., Cosinium fenestratum (Gaertn.) Coleb and Morinda umbellate L. are recommended as ayurvedic substitutes of Daruharidra and traded in the market. In ayurveda, it has been reported to be diaphoretic and diuretic; used as a tonic and also in the preparations of formulations for treating eye diseases, jaundice and skin diseases, diarrhoea, syphilis, chronic rheumatism, urinary disorders etc. From time to time, a number of reports on the various pharmacognosical and pharmacological properties of original Daruharidra (B. Aristata) and its substitutes have been reported. This review analyses traditional medicinal usage, and pharmacological and pharmacological investigations done on the endangered medicinal herb Daruharidra and its substitutes.
\end{abstract}

Keywords: Berberis aristata, antidiabetic, Phytochemical, antitoxidant.

I. Introduction

Herbal medicine is still the mainstay of about 75 $80 \%$ of the world population, mainly in the developing countries for primary healthcare. However among the estimated $250,000-400,000$ plant species, only $6 \%$ have been studied for biological activity, and about $15 \%$ have been investigated phytochemically ${ }^{1,}$ ${ }^{2}$. Therefore it seems necessary to evaluate the herbs properly. Charaka and Susruta have mentioned it's different properties along with various used for the treatment of numerous illnesses. As it resembles in its properties to those of haridra, both the herbs have been mentioned together as haridra dvaya, meaning two haridras viz. haridra and daruharidra. Berberine is a plant alkaloid with a long history of medicinal use in both Ayurvedic and Chinese medicine. It is present in Hydrastis Canadensis (goldenseal), Coptis chinensis (Coptis or goldenthread), Berberis aquifolium (Oregon grape), Berberis vulgaris (barberry), and Berberis aristata (tree turmeric). The berberine alkaloid can be found in the roots, rhizomes, and stem bark of the plants. Berberine extracts and decoctions have demonstrated significant antimicrobial activity against a variety of organisms including bacteria, viruses, fungi, protozoans, helminths, and chlamydia.

In China, berberine is an overthe counter drug for the treatment of bacterial diarrhea. In 1988, the hypoglycemic effect of berberine was firstly reported when berberine was prescribed to treat diarrhea in diabetic patients1. Moreover, several clinical and preclinical studies demonstrate ameliorative effect of 
berberine against several disorders including metabolic, neurological and cardiological problems. This review provides a summary regarding the pharmacokinetic and pharmacodynamic features of berberine, with a focus on the different mechanisms underlying its multispectrum activity.However, numerous literatures had been published by various authors exploring the phytochemical and pharmaceutical aspects along with traditional uses yet there is no much more literature concerning so far the importance of Berberine, which is important constituent of this species. English names are Indian barberry, tree turmeric. Indian names is darhaldi (Bengal), kashmoi (Garhwal), rasont, kashmal (Himachal Pradesh), chitra, dar hald, rasaut, kashmal (Hindi), maradarisina, maramanjal, (Kerala), daruhald (Maharashtra), chitra, chutro (Nepal),chitra, kasmal. simlu, sumlu (Punjab) mullukala, usikkala (Tamil Nadu), daruharidra, darvi, kata, pitadaru, suvarnavarna (Sanskrit).

\section{Figure 1: Different Stages of Berberis Aristata}

(I) Flower in Stage

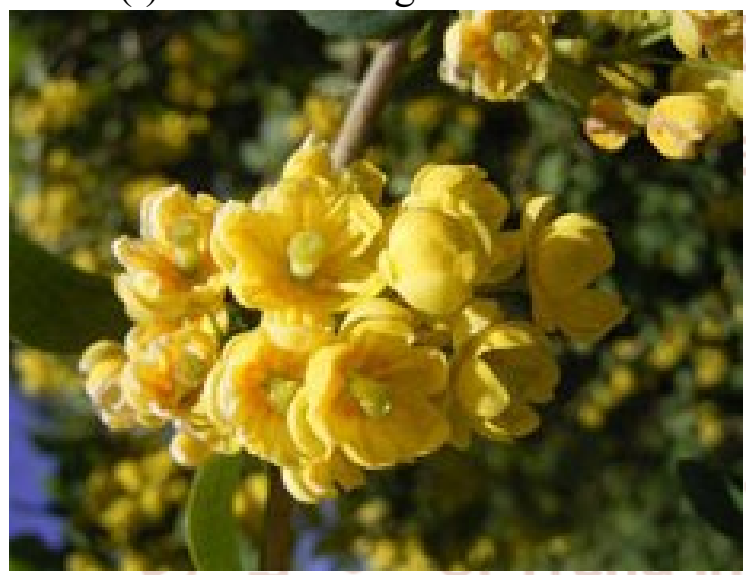

(II) Fruiting in Stage

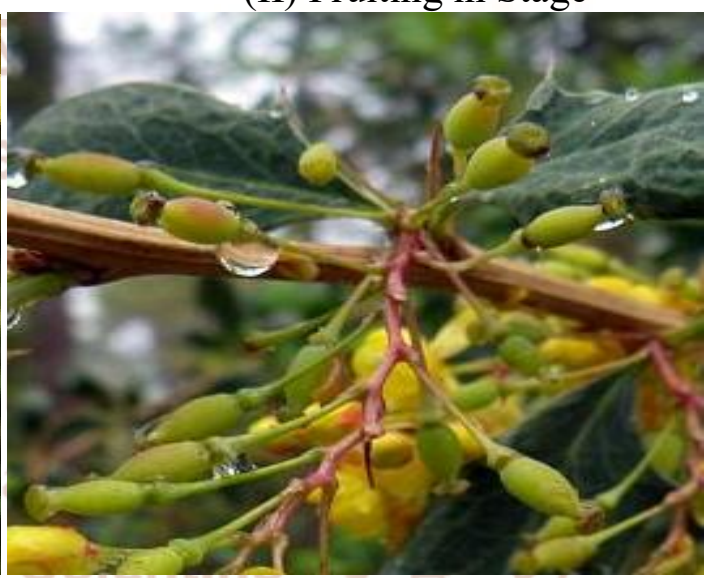

(IV) Berberis aristata seeds and fruit stage
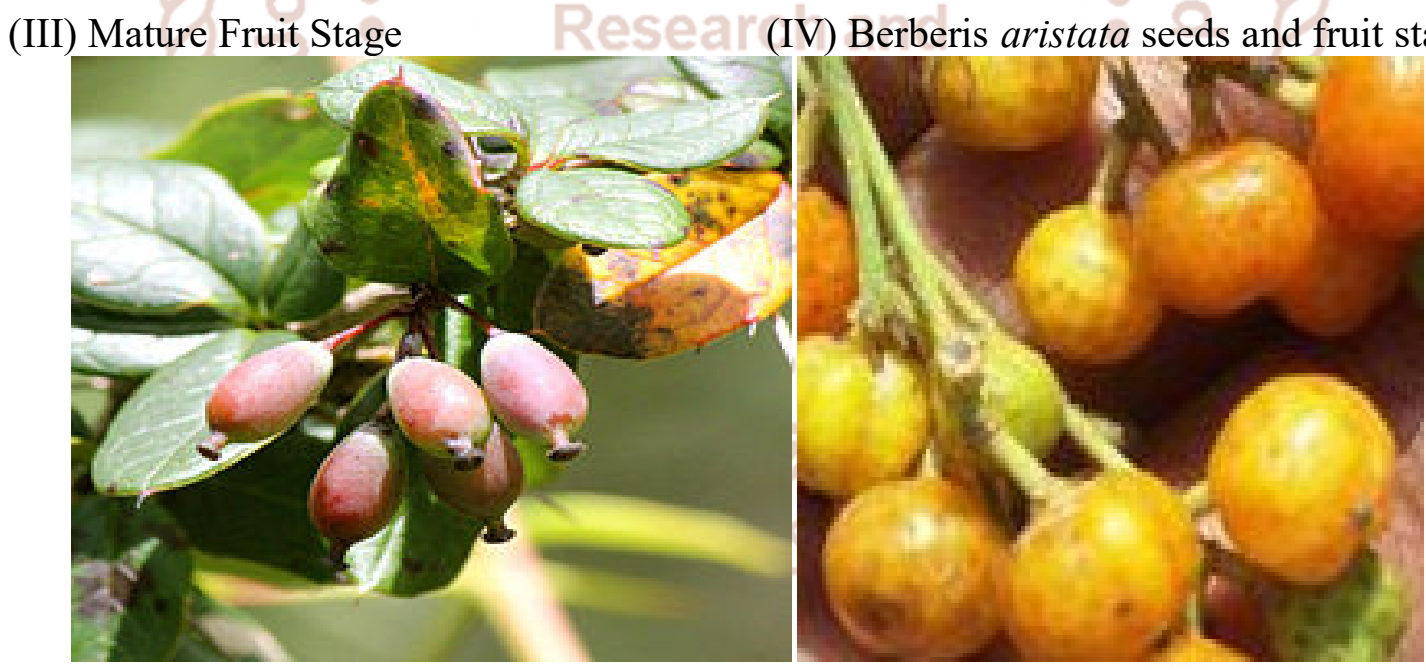

\section{History and Distribution}

This plant is widely distributed from Himalayas to Srilanka, Bhutan and hilly areas of Nepal in Himalaya region. It is found in Himachal Pradesh. It is also found in Nilgris hills in South India. ${ }^{3-7}$

\section{Botanical Description}

It is an erect spiny shrub, ranging between 3 to 4 meters in height wood, yellow and hard, bark, yellow to brown from outside and deep yellow from inside, removable in longitudinal strips by hand, spines, three branched and $2 \mathrm{~cm}$ long.

Leaves are in tufts of 6 to 9 , phyllotaxy verticillate, simple spiny, toothed, leathery, with reticulate pinnate venation $5 \mathrm{~cm}$ long, $2 \mathrm{~cm}$. Flowers are yellow, complete, cyclic, average diameter of a fully opened flower being $13 \mathrm{~mm}$; with 6 sepals, 4 to $5 \mathrm{~mm}$ long. Fruits are globose to ovoid, usually covered with 
bloom as in plums. Fruits are $7 \mathrm{~mm}$ long, $4 \mathrm{~mm}$ in diameter, weighing $226 \mathrm{mg}, 236$ micro liters in volume. Seeds are 2 to 5 in number, varying in colour from yellow to pink, each weighing $26 \mathrm{mg}$ and being 29 micro liters in volume. ${ }^{8,9}$

\section{Phytochemical studies}

The plant contains barberine, oxyberberine, berbamine, aromoline, karachine, palmatine, oxyacanthine and taxilamine. ${ }^{10}$ Berberis aristata contains protoberberine and bis isoquinoline type of alkaloid. Root of plant Berberis aristata contains alkaloid which are berbamine, Berberine, oxycanthine, epiberberine, palmatine, dehydrocaroline, jatrorhizine and columbamine, ${ }^{11,12}$ karachine, ${ }^{13}$ dihyrokarachine, taximaline, ${ }^{14}$ oxyberberine, aromoline. ${ }^{15}$ Four alkaloids, pakistanine, 1-O methyl pakistanine, pseudopalmatine chloride and pseudoberberine chloride were also isolated from Berberis aristata. ${ }^{16,17}$

Table 1: Parts of the Plant used for Various Compounds

\begin{tabular}{|l|l|l|}
\hline Species & Isolated active principals & Plant parts \\
\hline B. aristata & $\begin{array}{l}\text { Karachine }\left(\mathrm{C}_{26} \mathrm{H}_{27} \mathrm{O}_{5} \mathrm{~N}\right) \text {, melting point } 146-148^{\circ} \mathrm{C} \\
\text { - Taxilamine }\end{array}$ & Roots \\
\hline B. aristata & $\begin{array}{l}\text { Berberine, Palmitine, jatrohirine, colunbamamine Leaves \& Root } \\
\text { tetrahydropalmitine, berbamine, oxyberberine and oxyacanthine }\end{array}$ & \\
\hline
\end{tabular}

A secobisbenzlisoquinoline or simple isoquinoline alkaloid was isolated from Berberis aristata. ${ }^{18}$ The major alkaloid found in Berberis aristata is Berberine having yield of $2.23 \%$ followed by palamatine. ${ }^{19}$ Variation of Berberine content in root and stem of Berberis aristata with altitude was determined. It was found that plants growing at lower altitude have more Berberine content. Berberine content in plant is also influenced by potassium and moisture content of soil. ${ }^{20}$ HPTLC fingerprinting of Berberine in Berberis aristata was done to quantify the amount of Berberine. Total alkaloidal content of Berberis aristata was also done. ${ }^{21}$

Figure 2: Biosynthetic pathway of Berberine.

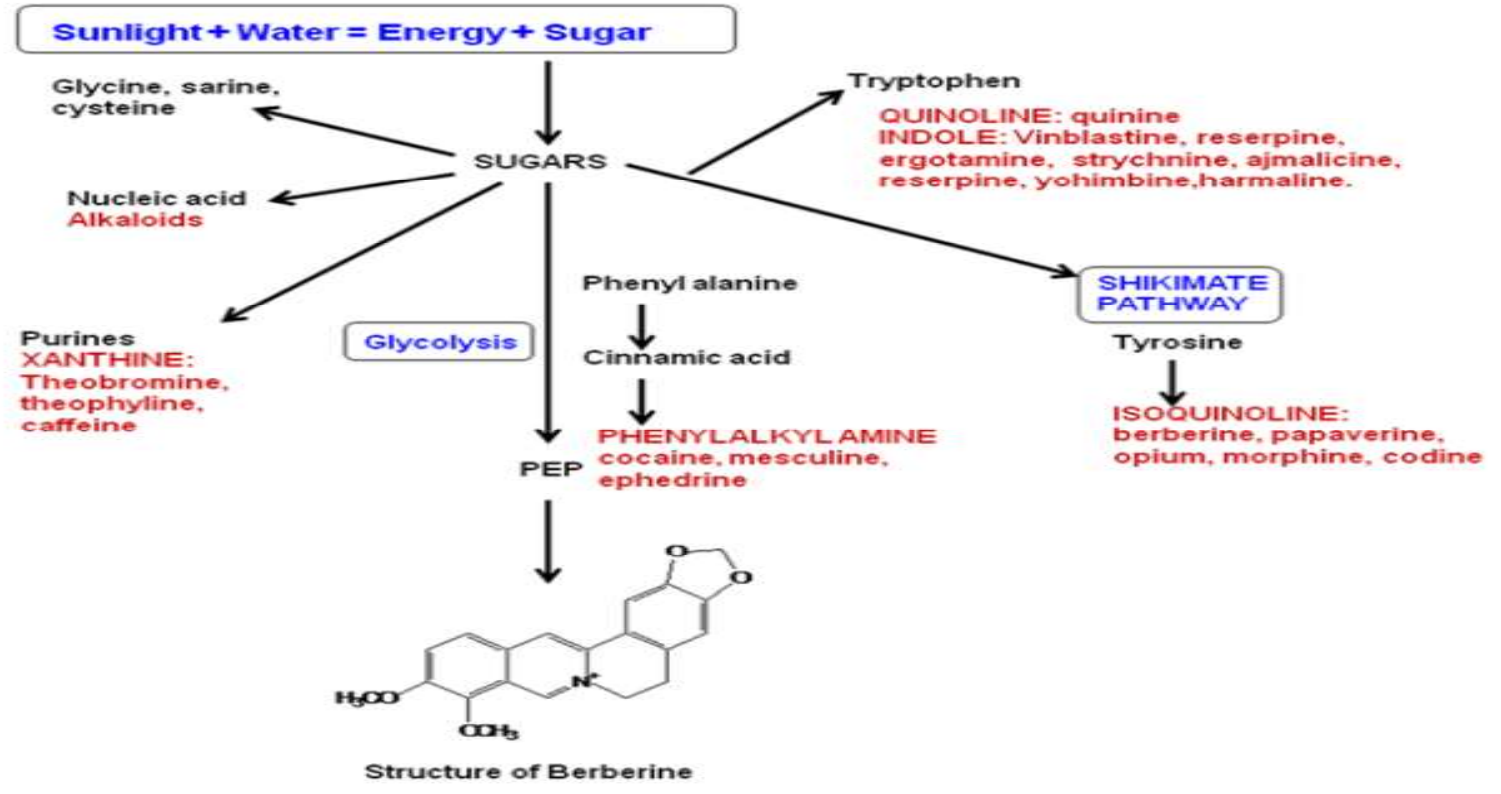

Structural Activity Relationship (SAR) of

Berberine Importantlyitcontains a quaternary base Berberine [Natural Yellow 18, 5,6-dihydro-9,10dimethoxybenzo(g)-1,3-benzodioxolo quinolizinium], a benzyl tetra isoquinoline plant alkaloid present in the roots and bark, which is also commercially available as various salts such as berberine chloride and hemisulfate. ${ }^{22}$ 
Figure 3: Chemical structure of Berberine

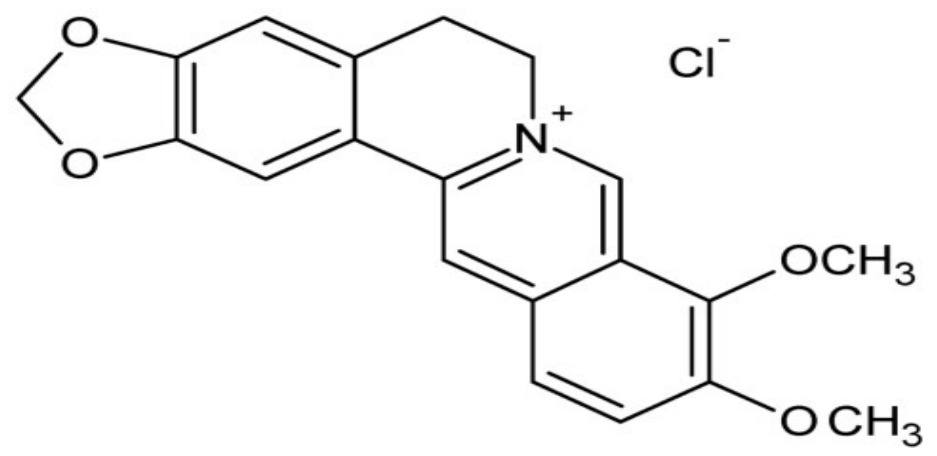

Berberine the main bioactive component present in the plant is known as an AMP activated protein kinase (AMPK) activator. It is insulin- independent hypoglycaemic. Its effect is related to inhibition of mitochondrial function, stimulation of glycolysis and activation of AMPK pathway and also prevents DNA replication. Carbonyl moiety plays a key role in the activity of these compounds and partial reduction of the carbonyl moiety led to inactive dihydroonycine. Modification of the 4-methyl group to a chloromethyl moiety enhanced as well as broadened the antifungal profile of azafluorenone.

\section{Pharmacological studies:}

\section{A. Antidiabetic activity:}

Berberine has shown marked impact on carbohydrate and lipid metabolism. Recent preclinical and clinical studies suggest that it has a strong impact on glucose homeostasis. In fact, berberine increases insulin receptor mRNA expression through kinase $\mathrm{C}$ dependent protein as promoter in cultured human liver cells and skeletal muscle. ${ }^{23}$ Berberine has been shown to provide protection against $b$-cell damage and protection of pancreas from oxidative stress in diabetic rats. In an animal study, diabetic and hyperlipidemic condition was induced in rats by intraperitoneal injection of $35 \mathrm{mg} / \mathrm{kg}$ streptozotocin and administration of high carbohydrate/high fat diet. The overall experiment was conducted by using seven groups of rats consisting of diabetic untreated and treated rats with $75 / 150 / 300 \mathrm{mg} / \mathrm{kg}$ berberine, rosiglitazone $4 \mathrm{mg} / \mathrm{kg}$ and fenofibrate $100 \mathrm{mg} / \mathrm{kg}$, and a control group. After 16 weeks of treatment, estimation of serum insulin level, insulin expression in pancreas, malonaldehyde content and superoxide dismutase activity in pancreas was carried out. It was observed that the diabetic rats showed alteration in pancreas to body weight ratio, insulin level, insulin sensitivity index, malonaldehyde content and superoxide dismutase activity. On the other hand, rats treated with 150 and $300 \mathrm{mg} / \mathrm{kg}$ berberine showed near control levels in the evaluating parameters.

Moreover, in diabetic rat's mitochondrial vacuolization, swelling and dilatation of $b$ cell endoplasmic reticulum in pancreas was observed. The pancreatic islets were found to be atrophied and the number of secretary granules was decreased in diabetic rats, but less pathological change was observed in rats treated with 150 and $300 \mathrm{mg} / \mathrm{kg}$ berberine. These findings strongly suggest that berberine has a protective effect for diabetes through increasing insulin expression, b cell regeneration, antioxidant enzyme activity and decreasing lipid peroxidation. ${ }^{24}$ Yin and colleagues have demonstrated scientific evidence for the use of berberine in human beings to treat type ${ }_{2}$ diabetes mellitus. ${ }^{25}$

This clinical study was conducted on two age groups with type 2 diabetes mellitus. In study A, 36 adult subjects were selected with newly diagnosed type 2 diabetes mellitus and were randomly assigned to treatment with berberine or metformin $(0.5 \mathrm{~g}$ three times daily) for 3 months. Periodically, the haemoglobin IC A1C, fasting blood glucose, postprandial blood glucose and plasma triglycerides were estimated. Significant decrease in haemoglobin Alc (from $9.5 \pm 0.5 \%$ to $7.5 \pm 0.4 \%, p<0.01$ ), fasting blood glucose (from $10.6 \pm 0.9$ to $6.9 \pm 0.5$ $\mathrm{mmol} / \mathrm{l}, \mathrm{p}<0.01$ ), postprandial blood glucose (from $19.8 \pm 1.7$ to $11.1 \pm 0.9 \mathrm{mmol} / \mathrm{l}, \mathrm{p}<0.01)$ and plasma triglycerides (from $1.13 \pm 0.13$ to $0.89 \pm 0.03 \mathrm{mmol} / 1$, $\mathrm{p}<0.05)$ were observed in the berberine group. The drug showed similar hypoglycemic effect to that of metformin. In study B, 48 adult subjects with poorly controlled type 2 diabetes mellitus were supplemented with berberine for a period of 3 months and were clinically evaluated, similar to that in study A.

Berberine was found to significantly decrease fasting blood glucose and postprandial blood glucose from week 1 until the end of the trial. Hemoglobin A1C decreased from $8.1 \pm 0.2 \%$ to $7.3 \pm 0.3 \%(p<0.001)$, while fasting plasma insulin and homeostasis model assessments of insulin resistance index were reduced by 28.1 and $44.7 \%$ ( $<<0.001)$, respectively. During the study, $20(34.5 \%)$ patients experienced transient gastrointestinal related adverse effects. Physiological functions of liver or kidney damage were not observed in any patient. Thus, this study indicates that 
berberine is a potent oral hypoglycemic agent that also has beneficial effects on lipid metabolism.

A recent study has investigated the molecular mechanism of berberine against insulin resistance, where the drug was found to increase insulin sensitivity through activation of insulin receptor (InsR). ${ }^{23}$ Berberine showed a dose and time dependent increase of InsR expression, InsR mRNA and protein expression in cultured human liver cells and L6 rat skeletal muscle cells. It was also observed that berberine enhanced InsR expression increases cellular glucose consumption only in the presence of insulin, and that berberine promotes InsR gene expression through a PKC dependent activation of its promoter.
Inhibition of PKC-abolished berberine caused InsR promoter activation and InsR mRNA transcription. In animal models, treatment of type 2 diabetes mellitus affected rats with berberine showed lowered fasting blood glucose and fasting serum insulin, increased insulin sensitivity and elevated InsR mRNA and PKC activity in the liver. In addition, berberine lowered blood glucose in KK Ay type ${ }_{2}$ but not in NOD/LtJ type 1 diabetes mellitus affected mice that were insulin deficient. The results suggest that berberine is a unique phytochemical constituent, active against insulin resistance in type 2 diabetes mellitus and metabolic syndrome.

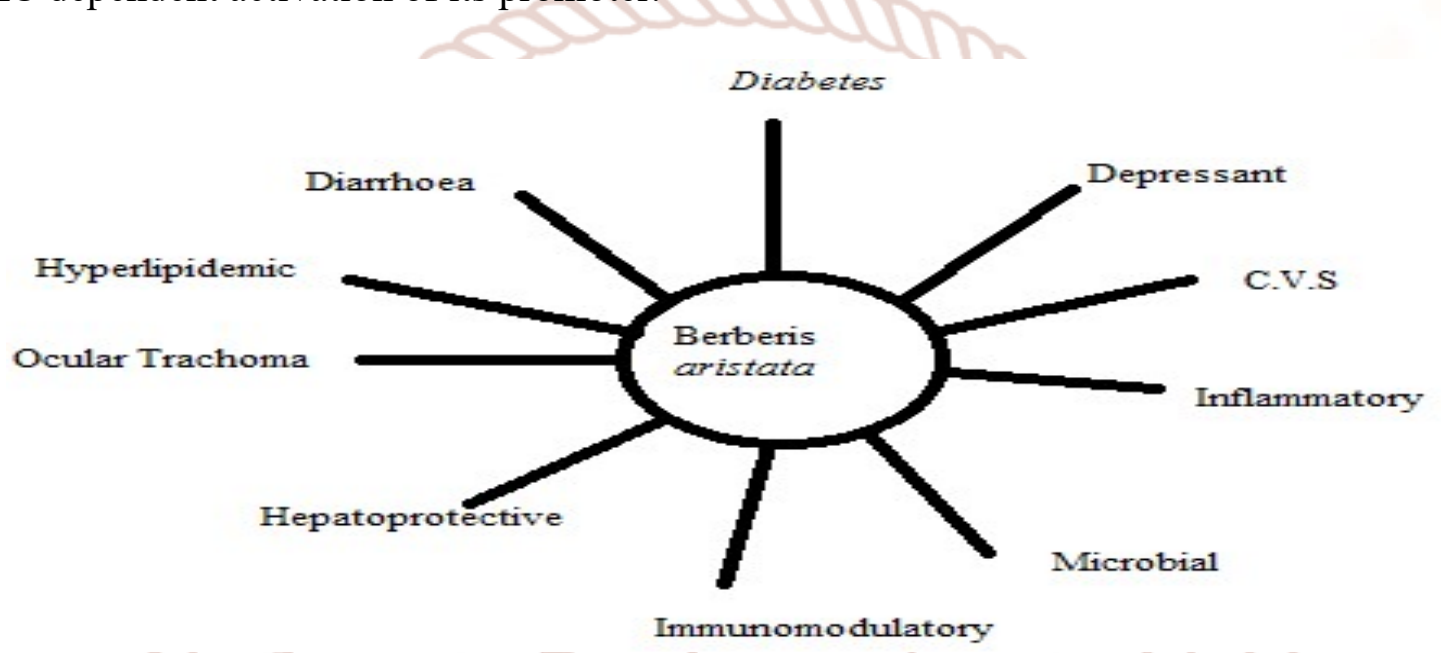

Figure 4: A broad spectrum of pharmacological activities of Berberis

\section{B. Antidepressant Activity:}

Recently, some neuropsychiatric research studies have investigated the CNS effects of berberine. Surprisingly, these studies demonstrated that berberine also possesses an antidepressant activity. ${ }^{26}$ It was found that the drug affected the signalling pathway of L-arginine-NO cGMP, which manifested the antidepressant activity of the drug. The antidepressant activity was confirmed by conducting forced swim test (FST) and tail suspension test (TST). ${ }^{27}$ Total immobility periods was recorded during a $6 \mathrm{~min}$ test. Berberine (5 -- $20 \mathrm{mg} / \mathrm{kg}$, i.p.) produced a reduction in immobility period in both tests. When berberine (5 $\mathrm{mg} / \mathrm{kg}$, i.p.) was coadministered with other typical antidepressant drugs such as mianserin $(32 \mathrm{mg} / \mathrm{kg}$, i.p.) or trazodone $(2$ $\mathrm{mg} / \mathrm{kg}$, i.p.), it was found to improve the anti immobility effect of sub effective doses of the two antidepressants in FST but did not modify their effects. Berberine ( $5 \mathrm{mg} / \mathrm{kg}$, i.p.) increased the levels of norepinephrine, serotonin or dopamine in the mouse whole brain, which was detected by using neurochemical analysis method. In yet another study, the effect of berberine in FST and TST on mouse was investigated. 28 In this study, berberine was administered in combination with atypical antidepressants with different mechanisms of action, including desipramine (noradrenaline [NA] reuptake inhibitor), serotonin (5-HT inhibitor), maprotiline (selective NA reuptake inhibitor), fluoxetine (selective 5 HT reuptake inhibitor) and moclobemide (monoamine oxidase [MAO] A inhibitor). The levels of these neurochemicals in mice striatum, hippocampus and frontal cortex were measured. The results show that berberine (10 and $20 \mathrm{mg} / \mathrm{kg}$, p.o.) significantly reduced the immobility time during the FST and TST. Furthermore, berberine $(20 \mathrm{mg} / \mathrm{kg})$ increased NA and 5 HT levels in the hippocampus and frontal cortex. The research results support the view that berberine exerts antidepressant activity. The antidepressant mechanism of berberine may be related to the increase in NA and 5 HT levels in the hippocampus and frontal cortex. 


\section{Anti inflammatory:}

B. aristata showed potent anti inflammatory activity against endotoxin induced uveitis in rabbits. Anterior uveitis was induced in rabbits by intravitreal injection of lipopolysaccharide from Escherichia coli after pretreatment with B. aristata aqueous extracts. ${ }^{29}$ The Berberis aristata plant was found to have moderate antiproteolytic activity towards trypsin induced hydrolysis of bovine serum albumin. ${ }^{30}$ The alcoholic extract may be acting by blocking the mediators released in the later phase, while the aqueous extract may be acting by blocking the mediators released in the early phase, as well as by blocking the mediators released in the later phase (i.e. Prostaglandin).

\section{Antimicrobial activity:}

The root extract of Berberine aristata shows antifungal activity. ${ }^{31}$ three extracts of $B$. aristata were tested for antifungal activity. All the 3 extracts showed antifungal activity against the Candida and aspergillus species tested, except c. Krusei out of the three types of extracts, the best results were obtained by using the alcoholic extract. Significant antifungal activity was found against Candida species and aspergillus species. $^{32}$

Above three extracts also shows wide antibacterial activity against gram positive bacteria. The extract was also tested for anti bacterial actively was limited against E. coli, S. typhimurium, S. dysenteriae type I and V. Cholera, the best activity being against V. cholera. The gram negative bacteria reported here as susceptible to the extracts of B. aristata are important human pathogens responsible for causing diarrhoea and dysentery. ${ }^{32}$ Berberis aristata was tested against eleven bacterial and eight fungal strains. B. aristat root extract gave low MIC's values against Bacillius cereus, Escherichia coli, staphylococcus aureus and Aspergillus flavus while stem extract against B. Cereus and Streptococcus pneumonia. ${ }^{33}$ Berberis Aristata also markedly inhibited the secretary response of E.Coli heat stable enterotoxin in the infant mouse model. ${ }^{34}$

Berberis Aristata shows effect against hepatitis infection. ${ }^{35}$ In vitro comparative study of antimicrobial activity of Berberis Aristata and berberine was also performed. ${ }^{36}$ The antimicrobial and anti diarrheal tests were conducted. The active principle, berberine was characterized by different spectroscopic and chromatographic techniques. ${ }^{37}$ Ethanolic extracts of B. aristata was tested for anti microbial activities by disc diffusion and broth dilution methods. The results from the disc diffusion method showed that B. aristata could inhibit the growth of propionibacterium acnes. 38

The clinical study was carried out to study its anti giardial activity and data suggest that berberine, administered orally, resulted in satisfactory parasitological cure, comparable to that obtained with other established antigiardial drugs. ${ }^{39}$ berberine sulphate salt on the growth of Trichomonas vaginalis in vitro was compared to the efficacy of metronidazole as regards to potency and can be used in possible replacement in metronidazole resistant cases. It has one more advantage of being safer. ${ }^{40}$

\section{E. Immunomodulatory Activity:}

The activity of a crude extract formulation was evaluated in experimental immunomodulation studies. The formulation comprises the following five plants are Boerhavia diffusa, Tinospora cordifolia, Berberis aristata, Terminalia chebula and Zingiber officinale. In immunomodulation studies humoral immunity was enhanced as evidenced by the haemagglutination titre. The T-cell counts remained unaffected in the animals treated with the formulation but cell-mediated immune response was stimulated as observed in the leukocyte migration inhibition (LMI) tests. ${ }^{41}$

\section{F. Influence on T-Cell Mediated Immunity:}

The protoberberine alkaloid berberin is isolated as a main alkaloid from the roots and bark of Berberis vulgaris. Berberine strongly inhibited in vitro the proliferative response of mouse spleen cells to $\mathrm{T}$ dependent mitogens concanavalin A (con A) and phytochemagglutinin (PHA). Spleen cells obtained from berberine treated mice $(10 \mathrm{mg} / \mathrm{kg} / 3)$ days $)$ expressed enhanced proliferative response to both mitogens. Berberine was applied to mice at different intervals before or after the induction of adjuvant arhritis (AIA) and Candida albicans (C. albicans) infection. The application of the alkaloid to new born mice ( 5 days after birth at a dose of $5 \mathrm{mg} / \mathrm{kg} / 3$ days) did not change the course of AIA and C. albicans infection. Its application at three 10 day intervals (5 $\mathrm{mg} / \mathrm{kg}$ ), starting from the 5 day after birth increased the joint inflammation in AIA. The host resistance to C. albicans infection was not affected, while the delayed type hypersensitivity (DTH) reaction against the pathogen was enhanced. The alkaloid inhibited the 
development of AIA when applied after its onset (10 $\mathrm{mg} / \mathrm{kg}$ from day +3 to +12 day).

Berberine treatment during the ongoing infection did not influence its outcome (from +2 to +10 day). Berbamine, an ingredient of Berberis, which itself is widely utilized in Chinese folk medicine has been used as a source of leukogenics, anti-arrhythmics and anti hypertensives. In recent years the immunosuppressive effects of berbamine has been demonstrated. In order to further investigate the value of berbamine as an immunosuppressive agent, the delayed type hypersensitivity reaction (DTH) response with sheep red blood cells (SRBC), the mixed lymphocyte reaction (MLR) and a skin model of allograft rejection on mice were studied. Berbamine showed suppressive effects on DTH and MLR and significantly prolonged allograft survival compared with untreated transplanted mice. The results indicate that berbamine may be a potential agent in clinical transplantation. ${ }^{42}$

\section{G. Hepatoprotective :}

In earlier studies, we demonstrated that this folkmedical use had scientifically justified-basis, as the crude extract of Berberis aristata leaves and fruits showed hepatoprotection possibly through inhibitory action on hepatic drug metabolizing enzymes. ${ }^{43,44}$ In this investigation we provide evidence that berberine is to be considered the active principle of these extracts. Berberine a known compound from Berberis aristata plant was studied for its possible anti hepatotoxicaction in rats. Pre treatment of animals with berberine $4 \mathrm{mg} / \mathrm{kg}$; orally twice daily for 2 days prevented the acetaminophen or $\mathrm{CCl} 4$ induced rise in serum levels of alkaline phosphatase ALP and aminotransaminases AST and ALT, suggestive of hepatoprotection. Post treatment with three successive oral doses of berberine $4 \mathrm{mg} / \mathrm{kg}$ every $6 \mathrm{~h}$ reduced the hepatic damage induced by acetaminophen, while CCl4 induced hepatotoxicity was not modified, suggesting a selective curative effect against acetaminophen. Pre treatment of animals with a single oral dose of berberine $4 \mathrm{mg} / \mathrm{kg}$ induced prolongation of the pentobarbital $60 \mathrm{mg} / \mathrm{kg}$, i.p. induced sleeping time as well as increased strychnine $0.3 \mathrm{mg} / \mathrm{kg}$; i.p. induced toxicity, suggestive of inhibitory effect on microsomal drug metabolizing enzymes, cytochrome P450s CYPs. ${ }^{45-47}$

\section{H. Ocular Trachoma Infections:}

A clinical study of aqueous berberine versus sulfacetamide for the treatment of Chlamydia trachomatis infection was conducted on 51 subjects in an outpatient eye clinic. It was determined that while sulfacetamide eye drops produced slightly better clinical results, conjunctival scrapings of these patients remained positive for the infective agent and relapses occurred. In contrast, the conjunctival scrapings of patients receiving the berberine chloride eye drops were negative for C. trachomatis and there were no relapses, even one year after treatment. It was also concluded that, while berberine chloride had no direct anti chlamydial properties, it seemed to cure the infection by stimulating some protective mechanism in the host. ${ }^{48} \mathrm{~A}$ second clinical study found berberine chloride superior to sulfacetamide in both the clinical course of trachoma and in achieving a drop in serum antibody titers against $C$. trachomatis. ${ }^{49}$

\section{Antidiarrhoeal activity:}

Study with berberine from the roots and barks of B. Aristata reported the inhibition of secretary response of heat labile enterotoxins of vibrio cholera and Escherichia coli in rabbit lighted intestinal loop model and infant mouse assay and possible clinical effectiveness in treating acute diarrheal disease. 40

\section{J. Other Effects:}

Berberine has demonstrated a number of other beneficial effects, including immunostimulation via increased blood flow to the spleen, macrophage activation, elevation of platelet counts in cases of primary and secondary thrombocytopenia, and increased excretion of conjugated bilirubin in experimental hyperbilirubinemia. 1 In addition, berberine may possess anti tumor promoting properties as evidenced by inhibition of COX-2 transcription and $\mathrm{N}$ acetyltransferase activity in colon and bladder cancer cell lines, ${ }^{50,51}$ and transient, but marked, inhibitory action on the growth of mouse sarcoma cells in culture. ${ }^{52}$

\section{K. Cardiovascular Effects}

Both clinical trials and animal research have indicated berberine administration prevented is chemiainduced ventricular tachyarrhythmia, stimulated cardiac contractility, and lowered peripheral vascular resistance and blood pressure. ${ }^{52,53}$ The mechanism for berberine's antiarrhythmic effect is unclear, but an 
animal study indicated it may be due to suppression of delayed after-depolarization in the ventricular muscle. ${ }^{54}$ An animal study suggested, in addition to affecting several other parameters of cardiac

performance, berberine may have a vasodilatory/hypotensive effect attributable to its potentiation of acetylcholine. ${ }^{55}$

Table 2: Ethno-pharmacological activities of the different of B. Aristata

\begin{tabular}{|l|l|}
\hline Part of the Plant & \multicolumn{1}{|c|}{ Ethno-pharmacological/clinical application } \\
\hline Fruits & $\begin{array}{l}\text { Preventive and curative effects on paracetamol } \\
\text { and CCl4 induced hepatotoxicity }\end{array}$ \\
\hline Root & Anti-platelet activating factor activity \\
\hline Stem, root bark and wood & Protection against ethanol-induced mitochondrial damage \\
\hline Fruit extract & Inotropic effect \\
\hline Root & Antihyperglycemic and antioxidant effect \\
\hline Root bark & $\begin{array}{l}\text { Scientific evidence for the folklore use of B. Aristata DC in urinary } \\
\text { troubles. }\end{array}$ \\
\hline Stem bark & Blood glucose lowering potential \\
\hline Root & Anti-diabetic activity \\
\hline Bark & Anti-diarrheal activity \\
\hline Stem & Hypoglycemic and hypolipidemic activity \\
\hline Root & Anti-osteoporotic activity in ovariectomized rats \\
\hline $\begin{array}{l}\text { Leaves and } \\
\text { Root }\end{array}$ & \begin{tabular}{l} 
Broad spectrum antimicrobial activity for the treatment of ear infections. \\
\hline Root
\end{tabular} \\
\hline Stem bark & Potentiation of thiopentone sodium induced hypnosis in rodents \\
\hline Leaves & Hypoglycemic activity of aqueous extract in STZ-induced rats \\
\hline
\end{tabular}

\section{Antihyperlipidemic activity}

The metabolic effects of berberine have been widely investigated in recent years. In lipid metabolism, it has been observed that berberine was capable of lowering lipid concentration by increasing the transcriptional activity of LDLR promoter by a JNK pathway and stabilization of hepatic LDL $\mathrm{C}$ receptor (LDLR) by an extracellular signal regulated kinase (ERK) dependent pathway. ${ }^{56,57}$ Moreover, the influence on $5 \phi$ AMPK and blocking of the MAPK/ERK pathway causes inhibition of lipid synthesis. ${ }^{58}$ The antihyperlipidemic action of berberine has also been confirmed in humans. ${ }^{59}$ In a clinical trial, 91 hypercholesterolemic people (52 males and 39 females) with types IIa and IIb hyperlipidemia were enrolled. Patients were divided into two groups: one group received $0.5 \mathrm{~g}$ berberine orally twice daily for a period of 3 months, while the other was maintained as a control group.

At the end of treatment, blood samples were collected and fasting serum concentration of cholesterol, triglycerides, high and low density lipoprotein cholesterol (HDL-C and LDL-C), as well as liver and kidney functions, were examined. Cholesterol levels were lowered by $18 \%$, triglycerides by $28 \%$ and LDLC by $20 \%$, without any significant change in HDL-C levels being observed, in 63 hypercholesterolemic patients. Moreover, berberine had no impact on kidney functions but improved liver function by reducing levels of alanine amino transferase, aspartate amino transaminase and gamma glutamyl transpeptidase enzymes. The control group showed no changes in any of the parameters examined. The results of the above clinical trial were re-evaluated in subjects who were neither on other drugs or herbs or nor on special diets before or during berberine therapy. In this study, $500 \mathrm{mg}$ of berberine was administered twice daily to 32 hyperlipidemic patients for a period of 3 months. The anti hyperlipidemic effect of the drug in this group was compared with 11 patients on placebo treatment. Berberine was found to significantly reduce the total cholesterol by $29 \%$, triglycerides by $35 \%$ and LDL-C by $25 \%$. In another clinical study, berberine and a combination of berberine with policosanol, red yeast extract, folic acid and astaxanthin was orally administered daily to 40 subjects with moderate dyslipidemias divided in two parallel groups, each of 20 subjects. 
After a period of 4 weeks the total cholesterol, LDLC, HDL-C, non-HDL, ApoB, ApoA, Lp(a) and triglycerides were estimated. Both berberine and the combination were found to significantly reduce TC (by 16 and $20 \%$, respectively), LDL (by 20 and $25 \%$ ), ApoB (by 15 and $29 \%$ ) and TG (by 22 and $26 \%$ ), as well as increasing HDL (by 6.6 and $5.1 \%$ ). It may be concluded that food supplements containing natural products such as those studied could be a useful support to diet and lifestyle changes to rectify dyslipidemias and to reduce cardiovascular risk in subjects with moderate mixed dyslipidemias. Moreover, adverse events or impairments of liver transaminases were not observed in the study, indicating the tolerability and safety of the drug in humans. ${ }^{.0}$

Table 3: List of major clinical trials conducted using berberine

\begin{tabular}{|c|c|c|c|c|c|}
\hline $\begin{array}{l}\text { SI } \\
\text { No }\end{array}$ & $\begin{array}{l}\text { Activity } \\
\text { studied }\end{array}$ & $\begin{array}{l}\text { No. } \\
\text { subject/groups }\end{array}$ & $\begin{array}{l}\text { Period of } \\
\text { study }\end{array}$ & Parameters evaluated & Study outcome \\
\hline \multirow[t]{3}{*}{1} & $\begin{array}{l}\text { Antihyperli } \\
\text { pidemic IIa }\end{array}$ & $\begin{array}{l}91 \\
\text { hypercholesterolemi } \\
\text { c people }\end{array}$ & 3 months & C, TG, HDL-C & Lowered SC by $18 \%$, \\
\hline & $\begin{array}{l}\text { and IIb } \\
\text { category }\end{array}$ & $\begin{array}{l}\text { (52 males and } 39 \\
\text { females); }\end{array}$ & $\diamond^{\circ} \circ$ & and LDL-C & $\begin{array}{l}\text { TG by } 28 \% \text { and LDL- } \\
\text { C by } 20 \%\end{array}$ \\
\hline & & $\begin{array}{l}\text { placebo group, } \mathrm{n}= \\
28\end{array}$ & & & $\begin{array}{l}\text { but no difference in } \\
\text { HDL-C level }\end{array}$ \\
\hline \multirow[t]{2}{*}{2} & $\begin{array}{l}\text { Antihyperli } \\
\text { pidemic }\end{array}$ & $\begin{array}{l}32 \text { hyperlipidemic } \\
\text { Asian patients; }\end{array}$ & 3 months & C, TG and HDL-C & $\begin{array}{l}\text { Reduced TC level by } \\
29 \% \text {, }\end{array}$ \\
\hline & & $\begin{array}{l}\text { placebo group, } \mathrm{n}= \\
11\end{array}$ & rend in & Scientific & $\begin{array}{l}\text { TG by } 35 \% \text { and LDL- } \\
\text { C by } 25 \%\end{array}$ \\
\hline \multirow[t]{3}{*}{3} & $\begin{array}{l}\text { Antihyperli } \\
\text { pidemic }\end{array}$ & $\begin{array}{l}40 \text { Caucasian } \\
\text { hyperlipidemic } \\
\text { patients; }\end{array}$ & 4 weeks & TG and LDL-C & $\begin{array}{l}\text { Reduced serum TG by } \\
26 \% \text { and }\end{array}$ \\
\hline & & $\begin{array}{l}\text { placebo group, } \mathrm{n}= \\
20\end{array}$ & & & $\begin{array}{l}\text { LDL-C by } 25 \% \text { in } \\
\text { combination dose and } \\
\text { reduced serum TG by } \\
22 \% \text { LDL C by } 20 \%\end{array}$ \\
\hline & & & & 0 & \\
\hline 4 & $\begin{array}{l}\text { Antidiabeti } \\
\text { c }\end{array}$ & $\begin{array}{l}36 \text { adults with newly } \\
\text { diagnosed type } 2 \\
\text { diabetes }\end{array}$ & 3 months & $\begin{array}{l}\text { Hemoglobin- } a 1 \text {, FPG, } \\
\text { postprandial glucose, } \\
\text { FPI }\end{array}$ & $\begin{array}{l}\text { Significant reduction in } \\
\text { hemoglobin- } a 1 \text { by } 2 \% \text {, } \\
\text { FPG by } 44 \% \text {, PPG by } \\
45 \% \text {, fasting plasma } \\
\text { insulin by } 28 \% \text { \& } \\
\text { HOMA IR index by } \\
44.7 \% \text { \& HOMA IR } \\
\text { index }\end{array}$ \\
\hline & & & & & \\
\hline \multirow[t]{3}{*}{5} & $\begin{array}{l}\text { Antihypert } \\
\text { ensive }\end{array}$ & $\begin{array}{l}100 \text { chronic heart } \\
\text { failure patients } \\
\text { (ventricular } \\
\text { tachyarrhythmia) }\end{array}$ & $\begin{array}{l}24--48 \mathrm{~h} \\
\text { ambulator } \\
\mathrm{y} \\
\text { monitoring }\end{array}$ & $\begin{array}{l}\text { Ventricular premature } \\
\text { contractions }\end{array}$ & $\begin{array}{l}>50 \% \text { reduction in } \\
\text { ventricular premature } \\
\text { contractions in } 62 \% \text { of }\end{array}$ \\
\hline & & & & & $\begin{array}{l}\text { patients and }>90 \% \\
\text { reduction in }\end{array}$ \\
\hline & & & & & $38 \%$ of patients \\
\hline
\end{tabular}


C: Cholesterol; FPG: Fasting plasma glucose; FPI: Fasting plasma insulin; HDL-C: High-density lipoprotein cholesterol; HOMA-IR: Homeostatic model assessment -- insulin resistance; LDL-C: Low-density lipoprotein cholesterol; PPG: Postprandial glucose; SC: Serum cholesterol; TG: Triglycerides.

\section{Conclusion:}

Berberis aristata is commonly found throughout India. Studies have revealed its use in antimicrobial, hepatoprotective, immunomodulatory, and anti depressant. However not much information is there to prove this plant for anti neoplastic, anti fertility, anti leprotic etc. therefore further studies may be carried out to prove the potential of this plant. The plant is becoming the endangered species now so more work can be done on agricultural and climatic conditions to grow this plant. The translational potential and clues to possible novel bioactivities and novel targets yet to be discovered with this amazing plant species can be gauged from the plethora of patents being awarded.

The plants are evaluated exhaustively for various pharmacological activities and reported to possess anti inflammatory, antiobesity, antifungal, antistress, antidiabetic, wound healing and fertility inducing activity. Berberis aristata safe antidiabetic property because proved the insulin stimulatory effect of this plant leaves from existing Beta cells in diabetic rats. Finally Berberis aristata is a safe drug in various ailments. Berberis aristata is commonly found throughout India. Review of literatures has revealed that Berberine as active component its use in antimicrobial, hepatoprotective, immunomodulatory, and anti depressant. Therefore further studies may be carried out to prove the potential of this plant. The plant is becoming the endangered species now so more work can be done on agricultural and climatic conditions to grow this plant. The translational potential and clues to possible novel bioactivities and novel targets yet to be discovered with this amazing plant species can be gauged from the period.

During the last few decades there has been an increase in the study of medicinal plants and their traditional use in different parts of the world. Reports of the folk medicine followed by critical scientific evaluation have given to the world newer sources as corrective, preventive and up to some extent curative measures in various diseases. Berberis species are among the most important traditional herbs with a vast array of pharmacological activities. The present review summarizes the taxonomic, ethno-botanical, pharmacognostic, photochemical and pharmacological claims of Berberis species. Literature on
Phytochemistry reveals that the species are rich in alkaloids, of which biologically active 'Berberine' is the major and potential one.

This review is a comprehensive documentation of various species belonging to this genus and their therapeutic potentials in the present context. Previous pharmacological studies on Berberis and its isolated alkaloids revealed more potential towards cardio vascular, hepatoprotective, antimicrobial and anticancer activities. Recent trend in research on Berberis species, however directed the workers to focus more towards oncology, toxicological studies and clinical trials. This review will be useful for researchers to approach the newer avenues by exploring varied pharmacological activities like anti diarrheal, antispasmodic, anti malarial, etc., which in turn will be more beneficial in developing myriads of scientifically validated herbal formulations containing naturally occurring biodynamic compounds.

\section{REFERENCES:}

1. Watt G. A dictionary of the economic products of India. Published under the authority of His Majesty's Secretary of State for India in Council, Kolkatta. London: Yohn Murry; 1889. p. 652.

2. Kirtikar KR, Basu BD. Indian medicinal plants. Allahabad: LM Basu Publication; 1933. p. 2422.

3. The Ayuredic pharmacopoeia of India, Government of India. MHFW, Department of AYUSH. 2007; 2(1):34-6.

4. The wealth of India publications and information Directorate CSIR, Delhi. 1985; 2:116-117.

5. Sabnarn SR. medicinal plant of Chammba, India. 1964; 90:50-63.

6. Shah NC, Joshi MC. An ethanobotanical study of the kumaon Region of Indian economic botany. 1971;25:414-422.

7. Chauhan Narain singh, Medicinal and aromatic plant of Himachal Pradesh, Indus publishing company, New Delhi. 114-116.

8. Parmar C, Kaushal MK. Berberis aristata, India. Wild Fruits, kalyani Publishers, New Delhi, India. 1982; 10-14. 
9. Rashmi , Rajashekaran A, Pant Jagdish. The genus berberis Linn; A Review, Pharmacognosy review. 2008;2(4):368-385.

10. Ambastha SP, editor. The Wealth of India, vol. 2B. Publication and Information Directorate. New Delhi: CSIR; 1988. p. 118.

11. Chatterjiee RP, Isolation of new phytoconstituents from the plants of Berberidaceae family. J Indian chem. Soc. 1951; 28:225.

12. Saied S, Batool S and Naz S. Phytochemical studies of berberis aristata, J of basic and applied sciences 2007; 3(1):1-4.

13. Blasko G, Karachine, an unusual protoberberine alkaloid. J of American chemical Society.1982; 104(7):2039-2041.

14. Blasko, Sharma M. Taxilamine: a Pseudobenzlypyroquinoline alkaloid. Heterocycle 1982; 19(2):257-9.

15. Atta ur Rahman, Ansari AA. Alkaloids of Berberis aristata - Isolation of Aromoline and Oxyberberine, J. Chem. Soc.Pak 1983; 5(4):283.

16. Bhakuni DS, Shoheb A, Popali SP. Medicinal plants: chemical constituent of berberis aristata. Indian journal of chemistry 1968; 6(2):123.

17. Lect EJ, Elango V, Hussain FS, Sharma M. Secobisbenzlisoquinoline or simple isoquinoline dimmer. Heterocycle 1983; 20(3):425-9.

18. Chakarvarti KK, Dhar DC, Siddhiqui S. Alkaloidal constituent of the bark of berberis aristata. $\mathrm{J}$ of scientific and industrial research 1950; 9b (7):161-4.

19. Ray and Roy, Folkloric uses of Berneris aristata. Sci and cult 1941; b13 (6).

20. Andola Harish Chandra, Gaira Kailash Singh, Singh Ranbeer Rawal, Rawat Mohan Singh Muniyari, Bhatt Indra Dutt. Habitat-Dependent Variations in Berberine Content of Berberis asiatica Roxb. ex. in Kumaon, Western Himalaya. Chemistry \& Biodiversity (DOI: 10.1002/cbdv.200900041) 2010.

21. Watt G. A dictionary of the economic products of India. Published under the authority of His Majesty's Secretary of State for India in Council, Kolkatta. London: Yohn Murry; 1889. p. 652.

22. Pereira CV, Machado NG, Oliveira PJ. Mechanisms of Berberine (Natural Yellow 18)Induced Mitochondrial Dysfunction: Interaction with the Adenine Nucleotide Translocator. Toxicolo Sci 2008; 105: 408-417.
23. Kong WJ, Zhang H, Song DQ, et al. Berberine reduces insulin resistance through protein kinase C-dependent up-regulation of insulin receptor expression. Metabolism 2009; 58:109-19.

24. Zhou J, Zhou S, Tang J, et al. Protective effect of berberine on beta cells in streptozotocin- and high-carbohydrate/ high-fat diet-induced diabetic rats. Eur J Pharmacol 2009; 606:262-8.

25. Yin J, Xing H, Ye J. Efficacy of berberine in patients with type 2 diabetes mellitus. Metabolism 2008; 57:712-17. Clinical study on the antidiabetic effect of berberine.

26. Kulkarni SK, Dhir A. Possible involvement of Larginine-nitric oxide (NO)-cyclic guanosine monophosphate (cGMP) signaling pathway in the antidepressant activity of berberine chloride. Eur J Pharmacol 2007; 569:77-83.

27. Kulkarni SK, Dhir A. On the mechanism of antidepressant-like action of berberine chloride. Eur J Pharmacol 2008; 589:163-72.

28. Peng WH, Lo KL, Lee $\mathrm{YH}$, et al. Berberine produces antidepressant-like effects in the forced swim test and in the tail suspension test in mice. Life Sci 2007; 81:933-8.

29. Gupta SK. The anti inflammatory effects of curcuma long and berberis aristata in endotoxin induced uveitis in rabbits.invest ophthalmol vis sci. 2008; 49(9):4036-40.

30. Gacche RN, Dhole NA. Antioxidant and possible anti inflammatory potential of selected medicinal plants prescribed in the Indian traditional system of medicine. 2006; 44(5):389-395.

31. Sharma R S, Mishraa V. Antifungal activity of some Himalayan medicinal plants and cultivated ornamental species. 2008; 79(8):589-91.

32. Shahid M, Rahim T. Ethnobotanical studies on berberis aristata DC. Afr J Bit. 2009; 8(4):556-63.

33. Singha M, Srovastava S. Antimicrobial activities of Indian berberis species. 2007; 78(7):574-63.

34. Bradley SR, Froehlich JL. Berberine inhibits intestinal secretory response of vibrio cholera and Escherichia coli enterotodins. Inf imm. 1982; 35(2):471-75.

35. Romero MR, Efferth T, Serrano MA. Effect of artesunate as inhibitors of hepatitis $\mathrm{B}$ virus production in an in vitro replicative system.2005; 68:75-83.

36. Pasrija A, Singh R, Sharma SK. Comparative study on antimicrobial activity of bereris aristata 
International Journal of Trend in Scientific Research and Development (IJTSRD) ISSN: 2456-6470

from different regions and berberine in vitro.2010;67-77.

37. Padmaja VJ, Atul AS. Antidiarrheal activity, chemical and toxicity profile of $b$. Aristata. Pha bio. 2011; 49(1):94-100.

38. Kumar GS, Jayveera KN, kumar CKA. Antimicrobial effects of Indian medicinal plants against acne inducing bacteria. Trop J Phar Res. 2007; 6(2):717-72.

39. Gupta S. Use of berberine in treatment of giardiasis. Am J Dis Child. 1975; 129(7):866.

40. Soffar SA, Metwali DM. Evaluation of the effect of a plant alkaloid on trichomonas vaginalis in vitro. J Eg Soc Par. 2001; 31(3):893-904.

41. Sharma PC, Yelne MB, Dennis TJ. Database on medicinal plants used in Ayurveda. Vol. 1. New Delhi: Central Council for Research in Ayurveda \& Siddha, 2000. p. 120-123.

42. India, Ministry of Health and Family Welfare. The Ayurvedic pharmacopoeia of India. Part I. Vol. II. New Delhi: Department of Indian Systems of Medicine \& Homeopathy, 2001. p. 34.

43. Singhal GD, Sharma KR. Ophthalmic and otorhinolaryngological considerations in ancient Indian surgery. Allahabad: Singhal Publications, 1976. 7-11.

44. Acharya JT. ed. Sushruta samhita. Varanasi: Chaukhamba Orientalia, 1980. 17-27.

45. Rabbani GH, et al., Randomized controlled trial of berberine sulfate therapy for diarrhea due to enterotoxigenic E. coli and Vibrio cholerae, Journal of Infectious Diseases 1987; 155(5): 979984.

46. Kaneda Y, et al., In vitro effects of berberine sulphate on the growth and structure of Entamoeba histolytica, Giardia lamblia, and Trichomonas vaginalis, Annals of Tropical Medicine and Parasitology 1991; 85(4); 417-425.

47. Chang HM and But PPH (editors), Pharmacology and Applications of Chinese Materia Medica, (volume 2), 1986 World Scientific, Singapore .3444.

48. Babbar OP, Chhatwal VK, Ray IB, Mehra MK. Effect of berberine chloride eye drops on clinically positive trachoma patients. Indian J Med Res 1982; 76:S83-S82.

49. Khosla PK, Neeraj VI, Gupta SK, Satpathy G. Berberine, a potential drug for trachoma. Rev Int
Trach Pathol Ocul Trop Subtrop Sante Publique 1992; 69:147-165.

50. Lin JG, Chung JG, Wu LT, et al. Effects of berberine on arylamine $\mathrm{N}$-acetyltransferase activity in human colon tumor cells. Am J Chin Med 1999; 27:265-275.

51. Fukuda K, Hibiya Y, Mutoh M, et al. Inhibition by berberine of cyclooxygenase- 2 transcriptional activity in human colon cancer cells. $J$ Ethnopharmacol 1999; 66:227-233.

52. Creasey WA. Biochemical effects of berberine. Biochem Pharmacol 1979; 28:1081-1084.

53. Chun YT, Yip TT, Lau KL, Kong YC. A biochemical study on the hypotensive effect of berberine in rats. Gen Pharmac 1978; 10:177-182.

54. Marin-Neto JA, Maciel BC, Secches AL, Gallo L. Cardiovascular effects of berberine in patients with severe congestive heart failure. Clin Cardiol 1988; 11:253-260.

55. Fukuda K, Hibiya Y, Mutoh M, et al. Inhibition of activator protein 1 activity by berberine in human hepatoma cells. Planta Med 1999; 65:381-383. Abidi P, Zhou Y, Jiang JD, Liu J. Extra cellular signal regulated kinase- dependent stabilization of hepatic low density lipoprotein receptor mRNA by herbal medicine berberine. Arterioscler Thromb Vasc Biol 2005; 25:2170-6.

56. Abidi P, Zhou Y, Jiang JD, Liu J. Extra cellular signal regulated kinase- dependent stabilization of hepatic low density lipoprotein receptor mRNA by herbal medicine berberine. Arterioscler Thromb Vasc Biol 2005; 25:2170-6.

57. Lee S, Lim HJ, Park JH, et al. Berberine-induced LDLR up-regulation involves JNK pathway. Biochem Biophys Res Commun 2007; 362:853-7.

58. Brusq JM, Ancellin N, Grondin P, et al. Inhibition of lipid synthesis through activation of AMP kinase: an additional mechanism for the hypolipidemic effects of berberine. J Lipid Res 2006; 47:1281-8.

59. Kong W, Wei J, Abidi $\mathrm{P}$, et al. Berberine is a novel cholesterol-lowering drug working through a unique mechanism distinct from statins. Nat Med 2004; 10:1344-51.

60. Cicero AF, Rovati LC, Setnikar I. Eulipidemic effects of berberine administered alone or in combination with other natural cholesterollowering agents. A single-blind clinical investigation. Arzneimittelforschung 2007; 57:2630 